\title{
The Impact of Macroeconomic Variables on the Non Performing Loans in the Albanian Banking System During 2005 - 2012
}

\author{
$\mathrm{PhD}$ Candidate, Ali Shingjergji \\ Lecturer in Portfolio Management and Investments Management \\ Finance and Accounting Department, Faculty of Economics \\ University of Elbasan "Aleksander Xhuvani", Albania \\ E-mail: ali.shingjergj@@gmail.com, Mobile: +3556962 35667
}

Doi:10.5901/ajis.2013.v2n9p335

\begin{abstract}
The aim of this paper is to analyze the impact of the main macroeconomic variables in the non performing loans' level in the Albanian banking system. This study is motivated by the hypothesis that macroeconomic variables have an effect on the non performing loans' level. The paper will be focused to find out the relations of the non performing loans ratio and the GDP, inflation rate, exchange rate euro/all and base interest rate by using a simple regression model. The Albanian banking system from 2008 is suffering from an ongoing growth level of the non performing loans and this is a big problem for the individual banks and for the banking system as a whole. Actually the level of non performing loans in the Albanian banking system is very concerning reaching up to $23.1 \%$ of the total loans. The Bank of Albania during the global financial crises has to be more vigilant of potential weaknesses of our banking system. This study is meant to be added to the actual field of research papers in the non performing loans issue.
\end{abstract}

Keywords: non performing loans, GDP, inflation, banking system, interest rate

\section{Introduction}

The last decade the Albanian banking system has made an extraordinary progress and now days are operating 16 private owned universal banks. The global financial crises of the 2008 that affected almost all the countries over the world did not save even the Albanian financial system. Given that the Albanian financial system is represented in its greater part from the banking system (85\%) the analysis and the identification of the problematic of the banking system that came as a result of global financial crises will take a great importance. In these conditions it is to stress that a very important indicator of the financial risks of the banks is credit risk which a lot of researchers connect directly with the level of non performing loans. In the Albanian banking system the NPL level appears in concerning levels and according the data of January 2013 the level of NPL reaches $23.1 \%$ of the total loans. It is understood that such a high level has been due to a gradual increase which has started since the last quarter of 2007 and continues now days to persist. The high level of NPL has forced the banks to reduce the number of new loans and it is normal that in these circumstances the ratio of NPL and total loans will increase. It is also to mention that the growth of this ratio comes not only as a result of the reduction of loan portfolio growth but also comes by the rapid pace of NPL's growth. In the last years despite the problems that the real economy is going through which continue to translate into a deterioration in the quality of the loan portfolio it is to mention that the Albanian banking system is well capitalized and highly liquid. As the banking system and businesses currently are facing a difficult period the last months the Bank of Albania has proposed a new anti-crisis package which is supposed to provide solutions to some of the most important problems facing the commercial banks and businesses in general. The anti-crises package will consist of three basic columns which are thought to give a positive impetus to the development and recovery of lending to the economy of our country. The package will focus on: legal column, monetary policy column and prudential column.

\section{Literature review}

In the last decade the NPL have had a greater emphasis almost all over the world as understood that a high and uncontrolled growth of NPL would lead to a potential failure of the banking system as a whole. It should also be mentioned that according to many researchers is confirmed that the cause of the collapse of banks is asset quality which 
is an important predictive of the banks insolvency. In the same time is confirmed that banks which are on the verge of bankruptcy are suffering from high levels of NPL just before the declaration of bankruptcy. Keeton and Morris in 1987 realize e study on 2.470 banks in the USA in order to understand why do banks' loan losses differ why differ in different banks. According to the authors some banks have higher losses as a result of pure chance, some from the weak process of credit management and some other banks have had the possibility to create well diversified loans portfolios which allowed banks to ease lending standards while keeping the total risk in low levels. Another explanation of the high loan losses is connected with banks which were situated in areas with unfavorable economic conditions. Boudriga, Taktak and Defi in 1997 analyze panel data of 59 countries to determine the factors affecting the NPL level. According to the empirical results is confirmed that a high level of capitalization, a prudent provision policy, concentration in banking industry and the foreign capital presence are the main determinants of the reduction of the NPL levels. The authors agree that the participation of the state in banks increases the NPL level. Keeton in 1999 analyzes the relation between the credit growth rate and the NPL ratio concluding that the fast growth rate of credit leads to higher loan losses and this relates to the supply shift that is an increased desire of the banks to give credit. The author stresses the fact that it will take 3 years that credit growth translate into NPL and as a result we have to analyze a long period to test statistically the fact that the fast credit growth leads to higher NPL. Fernández de Lis, Martínez Pagés and Saurina in 2000 analyze the cyclical behavior of bank credit, credit losses and credit provisions which are considered to be very cyclical in Spain. According to the authors there is a strong relation between the NPL ratio and the economic cycle suggesting that in economic booms the NPL ratio tend to be low and in economic downturn the NPL ratio tend to be relatively high. An important result is also that the credit expansion is one of the most important causes of the NPL ratio. The principal agent problem can amplify the credit expansion because the bank managers focus more to gain market shares than on shareholder returns. Fofack in 2005 analyzes the main causes of the NPL during the economic and banking crises that affected the Sub - Saharan African countries. The results of the analysis show that the high growth of NPL will lead us in an uncontrolled increase of credit risk. The real effective exchange rate, the real interest rate and GDP growth per capita are statistically significant while the credit risk especially tends to be high during sustainable economic downturns. Inflation rate is not important to explain the NPL dynamics that is in contradiction with other researchers results. Hess, Grimes and J. Holmes in 2008 analyze the determinant factors of loan losses in Australia taking data from 32 banks for a period that goes from 1980 - 2005. The authors divide the determinants of loan losses in two categories: macroeconomic and banking factors. According to the regression analysis is shown that the GDP growth and the change in unemployment rate have the expected effects on the dependent variable but with one year lag. The stock index and house price index are negatively related to the loan losses while the inflation growth rate is positively related with loan losses. Shijaku and Ceca in 2010 analyze the credit risk in the Albanian banking system which is identified by th NPL level. According to a statistical analysis the dependent variable was the NPL ratio (NPL/Total Loans) while the independent variables were: GDP growth, changes of Euribor and Libor, interest rate of loans, exchange rate ALL1/Euro and ALL/Dollar and the inflation rate. The regression coefficients had the expected signs and the GDP growth even is small in value is statistically significant. Kumar Dash and Gaurav Kobra in 2012 use the regression analysis for a 10 year period in order to examine the relation between the NPL level and some key macroeconomic and bank specific variables. The results show that e positive relation between the ratio of total loans and total assets suggesting that banks with a strong tendency to take risk have encountered higher levels of NPL. The credit growth, inflation rate and GDP growth has a negative relation with NPL levels while the real interest rate and the real effective exchange rate has a positive relation with NPL levels. Biabani, Gilaninia dhe Mohabatkhah in 2012 examine panel data from 2006 - 2011 to assess the effective determinants of the NPL level in Iran. Using a regression model they test the relation between the NPL level and loan collateral, duration of granted facilities' payment, having bounced check, having another deposit and credit background. The results show that all hypothesis are confirmed except the hypotheses testing the relation between the NPL level and having another deposit which has not a significant relation with NPL level.

\section{The non performing loans in Albanian banking system 2005 - 2012}

Actually there is not only one definition of the NLPs all over the world because different banking systems have different methods of classifying the loans. Anyway here we provide a general definition of non performing loans: A loan which

\footnotetext{
${ }^{1}$ Albanian Lek
} 
does not provide incomes anymore and: 1. Full payment of the principal and interest is not provided, 2 . Their payment is 90 or more days late, 3 . The maturity date has passed and the payment has not been completed.

Based on the Institute of International Finance in order to improve the cross - country comparison are used five categories of loans for reporting purposes: standard, watch, substandard, doubtful and loss loans. In some cases, NPLs correspond to the last three categories, in other only to doubtful and loss loans, in some cases only to loss loans while in the Albanian banking system the NPLs correspond to the last three categories. The period considered in this paper goes from the first quarter of 2005 till fourth quarter of 2012, a period long enough to catch the negative effects of the global financial crises of 2008. Analyzing the data the period is divided in two sub - periods: Q1 2005 - Q4 2008 and Q1 2008 Q4 2012. This division is made to evidence the effects of the financial crises on NPLs. The average NPLs ratio in the first period (pre crises) has been 3,45\% with a standard deviation of only 1,02\% showing a "natural" NPLs level for the banking system as a whole. In the second period (during crises) the average NPLs ratio is $15,46 \%$ while the standard deviation is $5,36 \%$. If we compare the average data of the two periods we can conclude that the NPLs ratio is fivefold greater in the second period than in the first period and the same thing for the standard deviation. Actually the NPLs ratio in the Albanian banking system is almost $24 \%$ showing an increased tendency and a higher credit risk over all. Now the banks should be aware of this higher credit risk not only by monitoring the problematic loans but even in the granting of new loans which recently have had a general slowdown. The banks now have identified the main factors that brought the rapid increase of NPLs, starting from the problems caused by the economic crisis, the decline of the incomes coming from emigration up to the reduction of incomes as a result of individuals being fired from their work. The situation is deteriorated even from banks mistakes such as banks being aggressive, especially regarding the loans in mortgages with cheap interest rates. The granting of new loans that was not fully examined and analyzed are bringing bad consequences now days and another important element to mention is the fact that the in Albanian banking system did not existed the Credit Register which was created only in 2008. In these conditions the businesses and individuals were able to be granted by more than one loan without being detected by the banks.

\section{Econometric model and estimation procedure}

Based on our review of the literature we notice that there is enough international evidence which suggests that NPLs may be explained by both macroeconomic and bank specific factors. We use panel data for the estimation procedure from first quarter of 2005 until fourth quarter of 2012.

We take into consideration this period to include even the effects of the global financial crises in the Albanian banking system toward the ongoing increase of the NPLs ratio especially form the fourth quarter of 2008.

In this paper we take into account only some macroeconomic factors which have to explain the dependent variable of NPLs ratio. We use the Ordinary Least Squares regression model to test the hypothesis and to realize the relations between the dependent variable and independent variables.

The following hypothesis will be tested:

H1. The GDP has a negative relationship with NPLs ratio;

H2. The inflation rate has a negative relationship with NPLs ratio;

H3. Base Interest Rate has a positive relationship with NPLs ratio;

H4. Foreign exchange rate between Euro and ALL has a positive relationship with NPLs ratio;

The dependent variable will be the NPLs ratio while as independent variables will be Inflation rate, GDP growth, Base interest rate and exchange rate Euro/All. The general regression equation will be:

LN_NPLt $=$ BO + B1LN_NPLt-4 + B2LN_GDPt + B3LN_INFt + ß4BIRt-4 + B5FXCt

LN_NPLt the natural logarithm of the ratio between non performing loans to total loans in time t;

LN_NPLt-4 natural logarithm of the ratio between non performing loans to total loans in time t-4;

LN_GDPt natural logarithm of GDP growth in \% in time t;

LN_INFt natural logarithm of inflation rate in time $t$;

BIRt-4 base interest rate in time t-4;

FXCt foreign exchange rate between Euro and Albanian Lek in time t;

\section{Data analysis and interpretation}

According to the data analysis of the Ordinary least squares estimation the results are presented in the table below. 
Table 1. Regression results

Dependent variable is LN_NPL

28 observations used for estimation from 2006Q1 to 2012Q4

\begin{tabular}{|l|c|c|c|c|}
\hline Regressor & Coefficient & Standard Error & T-Ratio & Probability \\
\hline CONSTANT & -21.5336 & 5.3073 & -4.0574 & 0.001 \\
\hline LN_NPL(-4) & 0.444174 & 0.147 & 3.0215 & 0.006 \\
\hline BIR(-4) & 11.0472 & 8.2248 & 1.3432 & 0.193 \\
\hline FCX & 0.03849 & 0.01354 & 3.7175 & 0.001 \\
\hline NL_GDP & 1.1114 & 0.3682 & 3.0185 & 0.006 \\
\hline LN_INF & -0.1856 & 0.086518 & -2.1452 & 0.043 \\
\hline
\end{tabular}

\begin{tabular}{|l|c|l|c|}
\hline R - Squared & 0.977449 & R - Bar Squared & 0.96869 \\
\hline S.E of Regression & 0.13433 & F - Stat F(5.22) & $168.0609(.0000)$ \\
\hline Mean of dependent Variable & -2.5173 & S.D of Dependent Variable & 0.75916 \\
\hline Residual Sum of Squares & 0.397 & Equation Log - likelihood & 19.854 \\
\hline Akaike Info. Criterion & 13.854 & Swchwarz Bayesion Criterion & 9.8574 \\
\hline DW - Statistic & 1.7286 & \multicolumn{2}{|l}{} \\
\cline { 1 - 3 }
\end{tabular}

The regression analysis confirms that the coefficient of determination R-squared is equal to $97.44 \%$ and shows that the independent variables explain $97.44 \%$ of the variation of the NPLs in the Albanian banking system. The DW - statistic is equal to 1.7286 indicating that the residuals are not correlated.

In the regression model LN_NPL(-4) used as an independent variable is statistically significant at lag 4 under 95\% level. According the results is noticed that NPLs ratio is positively related to previous year result.

The hypothesis number 1 is not confirmed showing a positive relationship between the GDP growth and the NPLs ratio. This is in fact contrary to international evidence of Fernández de Lis, Martínez Pagés and Saurina (2000), Fofack (2005), Hess, Grimes and J. Holmes (2008).

According the regression results beta is 1.1114 and is highly significant $(0.006)$ at $95 \%$ percent. This means that an increase of the GDP will translate in an increase of the NPLs ratio.

The hypothesis number 2 is confirmed demonstrating a negative relationship between inflation are and NPLs ratio. The beta coefficient is -0.1856 and is significant $(0.043)$ at $95 \%$ level. An increase by $1 \%$ of inflation rate will determine a reduction of $0.1856 \%$ of the NPLs ratio.

In fact the finding support the previous study conducted by Khemraj and Pasha (2009) and Fofack

(2005).

The hypothesis number 3 is not confirmed even if shows a positive relationship between the base interest rate of four quarters lag and NPLs ratio in time t. The beta coefficient 11.0472 but it is not significant because the probability is lower than $5 \%$. It is to mention that the base interest rate influences the NPLs ratio but this happens only with four quarter lags. The positive relationship of the coefficient demonstrates that the growth of base interest rate will determine an increase NPLs ratio in the Albanian banking system. In fact the base interest rate serves as the main indicator of inter banking lending in Albania and this rate influences all the other rate in one economy.

The hypothesis number 4 is confirmed showing a positive relationship between foreign exchange rate Euro/ALL and the NPLs ratio. The results of the regression show a beta of 0.03849 and is highly significant $(0.001)$ at $95 \%$ level. This result is very interesting taking into account that more than $50 \%$ of the granted loans in the Albanian banking system are in Euro currency. In this way the banks should be aware of this fact and take the right measures to reduce as much as they can the negative effects of an increase of FCX of Euro/ALL.

\section{Conclusions}

Non performing loans are very dangerous not only for the economy of one country but for the whole financial system in the world. In Albania the NPIs ratio is very concerning reaching levels of $23.1 \%$ of the total loans by setting the Albanian banking system in a higher credit risk. This credit risk has to be managed carefully by the supervisory authorities in order to avoid bankruptcies in the second level banks operating in Albania. This paper analyses the relationship between the NPLs ratio and some macroeconomic variable. From the regression analysis is noticed a positive relationship between the GDP growth and the NPLs ratio that is contrary to international evidence. In fact is expected that a GDP growth will 
lead to a reduction of the NPLs ratio because all subjects in one economy when getting higher incomes will be more capable to repay their debts and this will be translated into lower NPLs ratios.

According to international evidence the inflation rate is negatively related with NPLs ratio even in the Albanian banking system.

From the results we find a positive relationship between the base interest rate of four quarters lag and NPLs ratio in time t. The supervisory authorities should take into account this fact when determining their monetary policies to avoid the negative effects of NPLs ratio when they decide to increase the base interest rate.

An important finding of this paper consists in the positive relationship between foreign exchange rate Euro/ALL and the NPLs ratio. This is an essential fact taking into account that more than $50 \%$ of the granted loans in the Albanian banking system are in Euro currency. For this the borrowers will be almost always exposed to the foreign exchange rate of Euro/ALL and will lead to a higher NPLs ratio. We hope that this paper will contribute to the existing literature in this field and further studies can be done taking into account other variables specifically those form the banks.

\section{References}

William R. Keeton and Charles S. Morris 1987 "Why do banks' loan losses differ?" Federal Reserve Bank of Kynsas City, Economic Review, 3-21.

William R. Keeton "Does Faster Loan Growth Lead to Higher Loan Losses?”, Economic Review, Second Quarter 1999,

Santiago Fernández de Lis, Jorge Martínez Pagés and Jesús Saurina. "Credit growth, problem loans and credit risk provisioning in Spain", Banco de España - Servicio de Estudios Documento de Trabajo n. ${ }^{0} 0018$, October 2000.

Fofack, H., 2005. "Non Performing Loans in Sub-Saharan Africa: Causal Analysis and Macroeconomic Implications". World Bank Policy Research Working, Paper 3769.

Hess, Grimes and J. Holmes in 2008. "Credit Losses in Australasian Banking". Department of Economics Working Paper in Economics 08/10 June 2008.

Shijaku and Ceca in 2010. "A model for credit risk in Albania using banks' panel data". Economic policies in SEE: design, performance and challenges, November 2010. $53-72$.

Dash, M., and Kabra, G. (2010). "The determinants of non-performing assets in Indian commercial bank: An econometric study". Middle Eastern Finance and Economics, 7, 94-106.

Biabani, Gilaninia dhe Mohabatkhah 2012. "Assessment of Effective Factors on Non-Performing Loans (NPLs) Creation:Empirical Evidence from Iran (2006-2011)". J. Basic. Appl. Sci. Res., 2(10)10589-10597, 2012.

Farhan, Sattar, Chaudhry and Khali 2012. "Economic Determinants of Non-Performing Loans: Perception of Pakistani Bankers" European Journal of Business and Management, Vol 4, No.19, 2012.

Statistical data of the Albanian banking system: http://www.aab.al/al/statistics.php.

Statistical data from the Bank of Albania: http://www.bankofalbania.org/web/Statistika_230_1.php.

Statistical data from INSTAT institution: http://www.instat.gov.al/al/home.aspx. 